\title{
Morphological, Biometrical, Biochemical, and Molecular Characterization of the Coffee Root-Knot Nematode Meloidogyne megadora
}

Carla M. Maleita, Chemical Process Engineering and Forest Products Research Centre (CIEPQPF), Department of Chemical Engineering, University of Coimbra (UC), P-3030 790 Coimbra, Portugal; Ana M. S. F. de Almeida, Instituto Piaget, Escola Superior de Saúde de Silves, Enxerim P-8300 025 Silves, Portugal; Nicola Vovlas, Institute for Sustainable Plant Protection, 70126 Bari, Italy; and Isabel Abrantes, Centre for Functional Ecology, Department of Life Sciences, UC, P-3000 456, Coimbra, Portugal

\begin{abstract}
Maleita, C. M., de Almeida, A. M. S. F., Vovlas, N., and Abrantes, I. 2016. Morphological, biometrical, biochemical, and molecular characterization of the coffee root-knot nematode Meloidogyne megadora. Plant Dis. 100:1725-1734.

Meloidogyne megadora infects coffee trees, an economically important crop worldwide. The accurate identification of M. megadora is essential for the development of preventive measures to avoid the dispersion of this pathogen and establishment of efficient and sustainable integrated pest management programs. One M. megadora isolate was studied by biometrical, biochemical, and molecular characteristics (random amplified polymorphic DNA [RAPD] and PCR of internal transcribed spacer [ITS] region). Biometrical characteristics of $M$. megadora females, males, and second-stage juveniles were similar to the original description. Biochemical studies revealed a unique enzyme pattern for M. megadora esterases (Me3) that allowed for species differentiation. Three RAPD primers (OPG-4, OPG-5, and OPG-6) produced specific bands to all

Meloidogyne spp. studied: M. megadora, M. arenaria, M. incognita, and $M$. javanica. Molecular analysis of the ITS region resulted in an amplification product of $700 \mathrm{bp}$. The phylogenetic relationship between M. megadora and several Meloidogyne spp. sequences was analyzed, revealing that $M$. megadora clearly differs from the most common root-knot nematode species. Based on the studies conducted, isozyme analysis remains a useful and efficient methodology for $M$. megadora identification when females are available. Further studies will be needed to convert the $M$. megadora differential DNA fragment obtained by RAPD and develop a species-specific sequence-characterized amplified region PCR assay for its diagnosis based on second-stage juveniles.
\end{abstract}

Root-knot nematodes (RKN; Meloidogyne spp.) are distributed worldwide and have a substantial economic impact on agricultural areas, inclusively causing damage in almost all coffee-producing regions (Campos et al. 1990). Total global production of green coffee was 8.8 million tons, with South America being the world's largest producer (58.1\%), followed by Asia (29.6\%), Africa (11.3\%), and, finally, Oceania (1\%) (FAO 2012). The genus Meloidogyne contains over 90 described species and, based on morphological features of females, males, and second-stage juveniles (J2) and esterase and malate dehydrogenase isozyme profiles, 17 have been associated with coffee in many countries worldwide: Meloidogyne africana Whitehead, 1959; M. arabicida López and Salazar, 1989; M. arenaria (Neal, 1889) Chitwood, 1949; M. coffeicola Lordello and Zamith, 1960; M. decalineata Whitehead, 1968; M. exigua Göldi, 1887; M. hapla Chitwood, 1949; M. incognita (Kofoid and White, 1919) Chitwood, 1949; M. inornata Lordello, 1956; M. izalcoensis Carneiro, Almeida, Gomes and Hernández, 2005; M. javanica (Treub, 1885) Chitwood, 1949; M. kikuyensis De Grisse, 1961; M. konaensis Eisenback, Bernard and Schmitt, 1995; M. enterolobii Yang and Eisenback, 1983 (= M. mayaguensis Rammah and Hirschmann, 1988); M. megadora Whitehead, 1968; M. oteifae Elmiligy, 1968; and M. paranaensis Carneiro, Carneiro, Abrantes, Santos and Almeida, 1996 (Carneiro and Cofcewicz 2008).

Research on morphological, biochemical, and molecular characterization and identification, reproduction mode, chromosome number, distribution, life cycle, and host range has been performed for

Corresponding author: C. M. Maleita; E-mail: carlamnmaleita@ hotmail.com

GenBank accession numbers of nucleotide sequences: KU559895, KU559896, and KU559897.

Accepted for publication 28 March 2016.

http://dx.doi.org/10.1094/PDIS-01-16-0112-RE

(C) 2016 The American Phytopathological Society some of these coffee-parasitic Meloidogyne spp. but few studies included $M$. megadora, which can be confused with other RKN species. Only recently, the electrophoretic esterase phenotype (Me3) has been used to differentiate $M$. megadora from the other coffee species (Maleita et al. 2012). An RKN found in coffee nurseries and plantations in São Tomé, Democratic Republic of São Tomé and Príncipe, was initially characterized and identified as $M$. decalineata (Lordello and Fazuoli 1980; Santos et al. 1992). Further studies and comparison of the perineal patterns of the nematode with species paratypes showed that the identification was not correct and, hence, the RKN has been identified as M. megadora (Abrantes et al. 1995a,b).

M. megadora has been found in few African countries. It was first described as the cause of root galling of coffee trees-Coffea arabica L., C. canephora Pierre, C. congensis Frohna, and C. eugenioides S. Moore-in Amboim, Angola (Whitehead 1968). Since 1968, M. megadora has also been reported in Sudan, associated with several important plant species (Decker et al. 1980; Yassin and Zeidan 1982); in China, on banana (Musa paradisiaca L. var. sapientum) (Yassin and Zeidan 1982; Zhang and Weng 1991); and in Uganda, on coffee (Whitehead 1969). The host status of several cultivated plants to M. megadora was already evaluated and resistance to this species exists in several plant cultivars; however, some species were recorded as susceptible: Cucumis melo L., C. sativus L., Ipomoea batatas L., M. acuminata L., M. paradisiaca L., M. sapientum L., Phaseolus vulgaris L., Pisum sativum L., and Vicia faba L. (Almeida and Santos 2002; Almeida et al. 1997).

The purposes of this research were to characterize one isolate of Meloidogyne megadora by morphological and biometrical characteristics, using light and scanning electron microscopy, biochemistry (esterase and malate dehydrogenase activity), and molecular analyses to clarify the diagnosis of the species. Morphology and biometrical results were compared with those of the original species description (Whitehead 1968). The genetic diversity and relationships between M. megadora and RKN isolates belonging to the most common species using the profiles obtained with random amplified polymorphic DNA (RAPD) markers and the sequence of internal transcribed spacer (ITS) region between $18 \mathrm{~S}$ and $28 \mathrm{~S}$ of ribosomal RNA (rRNA) genes were evaluated. 


\section{Materials and Methods}

Nematode isolate. Coffee plants (Coffea arabica 'Catuaí Amarelo' and C. canephora 'Robusta') with large root galls were found in a coffee nursery and in coffee plantations in São Tomé, Democratic Republic of São Tomé and Príncipe. Egg masses of one of the populations

Table 1. Meloidogyne isolates included in molecular studies (RAPD-PCR), hosts and geographic origin

\begin{tabular}{|c|c|c|}
\hline $\begin{array}{l}\text { Species, race } \\
\text { (isolate code) }\end{array}$ & Host plant & Geographic origin \\
\hline $\begin{array}{l}\text { Meloidogyne arenaria } \\
\text { (Neal, 1889) } \\
\text { Chitwood, 1949, } \\
\text { race } 3 \text { (ATo) }\end{array}$ & $\begin{array}{l}\text { Cucumis melo L., } \\
\text { Solanum lycopersicum L. }\end{array}$ & Azambuja, Portugal \\
\hline $\begin{array}{l}\text { M. incognita (Kofoid } \\
\text { and White, 1919) } \\
\text { Chitwood, 1949, } \\
\text { race } 2 \text { (ITo) }\end{array}$ & Brassica oleracea L. & Monte Café, S. Tomé \\
\hline $\begin{array}{l}\text { M. javanica (Treub, } \\
\text { 1885) Chitwood, } \\
\text { 1949, race } 1 \\
(\text { J1To, J1Be) }\end{array}$ & $\begin{array}{l}\text { S. tuberosum L., } \\
\text { Phaseolus vulgaris L. }\end{array}$ & Guarda, Portugal \\
\hline $\begin{array}{l}\text { M. javanica, race } 2 \\
(\mathrm{~J} 2 \mathrm{To}, \mathrm{J} 2 \mathrm{Be})\end{array}$ & Coffea arabica $\mathrm{L}$. & Bemposta, S. Tomé \\
\hline $\begin{array}{l}\text { M. megadora } \\
\text { Whitehead, } 1968 \\
\text { (MeBe) }\end{array}$ & C. arabica $\mathrm{L}$. & Monte Café, S. Tomé \\
\hline
\end{tabular}

Table 2. Random amplified polymorphic DNA primers used in this study

\begin{tabular}{lc}
\hline Primer name & Primer sequence $\left(\mathbf{5}^{\prime} \rightarrow \mathbf{3}^{\prime}\right)$ \\
\hline OPG-04 & AGCGTGTCTG \\
OPG-05 & CTGAGACGGA \\
OPG-06 & GTGCCTAACC \\
OPG-09 & CTGACGTCAC \\
SC $10-30$ & CCGAAGCCCT \\
SC $10-87$ & CGTGGGGGGC \\
\hline
\end{tabular}

found on C. arabica 'Catuaí Amarelo' were used to establish cultures on this host. Five coffee seedlings were transplanted singly into pots containing a steam-sterilized sandy loam soil and inoculated with 5,000 eggs $+\mathrm{J} 2 /$ plant. Plants were allowed to grow for 3 to 6 months in a growth chamber at $25 \pm 2{ }^{\circ} \mathrm{C}$ and 70 to $75 \%$ relative humidity. To rule out that the original population consisted of a mixture of species, a single egg-mass isolate was raised on bean-Phaseolus vulgaris L. 'Vermelho Mocho' or 'Bencanta Trepar' - and maintained by periodic subculturing, in the Nematology Laboratory (Centre for Functional Ecology-University of Coimbra; Almeida et al. 1997). Another four Meloidogyne spp. and races were included in the molecular studies (RAPD PCR) for comparison (Table 1).

Biometrical characterization. Adult females and males, J2, and female perineal patterns were prepared for light microscopy and scanning electron microscopy (SEM), as previously described (Abrantes and Santos 1991). Adult males were recovered from infected roots, $\mathrm{J} 2$ hatched from egg masses in moist chambers, and adult females handpicked from infected roots. Stylets of $\mathrm{J} 2$ and adult males and females were also prepared for SEM as described by Abrantes and Santos $(1989,1991)$ and Eisenback (1985). At least 20 specimens of each life stage, from coffee and bean, were examined.

Differential host test. Seedlings of the North Carolina differential hosts (Taylor and Sasser 1978) were transplanted separately into pots $(7 \mathrm{~cm}$ in diameter) filled with a mixture of sterilized sandy loam soil and sand (1:2). As positive controls, additional pots were planted with bean 'Bencanta Trepar' (Almeida et al. 1997). $M$. megadora eggs were extracted from infected bean roots with $0.52 \%$ sodium hypochlorite $(\mathrm{NaOCl})$ solution (Hussey and Barker 1973). Three plants of each differential host plant cultivar were inoculated with 5,000 eggs and the pots were arranged in a completely randomized design in a growth chamber at $25 \pm 2{ }^{\circ} \mathrm{C}$ and 70 to $75 \%$ relative humidity. Sixteen days after inoculation, the plants were uprooted and the roots were washed free of soil and stained with Phloxine B (Hartman 1982). Numbers of galls and egg masses were recorded and an index of 0 to $5(0=$ no galls or egg masses and $1=1$ to $2,2=3$ to $10,3=11$ to $30,4=31$ to 100 , and $5>100$ galls or egg masses per root) was assigned (Taylor and Sasser 1978). Plants with an average gall or egg masses index $\leq 2$ were considered as nonhosts and $>2$ as hosts (Hartman and Sasser 1985).

Table 3. Morphometric comparison of Meloidogyne megadora Whitehead, 1968 females from coffee and bean ${ }^{\mathrm{a}}$

\begin{tabular}{|c|c|c|c|}
\hline Characteristic & Coffee $(n=20)^{b}$ & Bean $(n=20)^{\text {c }}$ & Coffee $(n=12)^{\mathrm{d}}$ \\
\hline \multicolumn{4}{|l|}{ Linear $(\mu \mathrm{m})$} \\
\hline Body length (L) & $1118.3 \pm 203.1(830.0-1520.0)$ & $1123.8 \pm 104.2(925.0-1360.0)$ & $683 \pm 87(554-845)$ \\
\hline Body length without neck & $918.0 \pm 205.5(650.0-1320.0)$ & $924.3 \pm 76.5(690.0-1120.0)$ & $\ldots$ \\
\hline Body width (W) & $569.5 \pm 81.2(440.0-750.0)$ & $567.9 \pm 71.3(450.0-720.0)$ & $\ldots$ \\
\hline Neck length & $205.3 \pm 42.7(110.0-300.0)$ & $193.8 \pm 52.7(135.0-310.0)$ & $\ldots$ \\
\hline Neck width & $146.3 \pm 38.0(90.0-225.0)$ & $161.5 \pm 25.4(130.0-220.0)$ & $\ldots$ \\
\hline Lip region to posterior end of metacorpus & $103.5 \pm 12.6(82.0-125.0)$ & $\ldots$ & $\ldots$ \\
\hline Lip region to excretory pore & $33.3 \pm 4.3(26.0-40.0)$ & $38.5 \pm 5.3(32.0-55.0)$ & $\ldots$ \\
\hline Stylet length & $15.4 \pm 0.9(14.0-16.5)$ & $14.7 \pm 0.6(13.0-15.3)$ & $15(13-17)$ \\
\hline Stylet knob height & $2.6 \pm 0.4(2.0-3.0)$ & $2.2 \pm 0.2(2.0-2.8)$ & $\ldots$ \\
\hline Stylet knob width & $4.4 \pm 0.4(4.0-5.0)$ & $3.9 \pm 0.2(3.3-4.0)$ & $3(3-5)^{\mathrm{e}}$ \\
\hline Dorsal esophageal gland orifice to stylet base & $5.8 \pm 0.6(5.0-6.5)$ & $5.4 \pm 0.6(4.0-6.5)$ & $6.0(4.0-8.0)^{\mathrm{e}}$ \\
\hline Metacorpus valve length & $16.1 \pm 1.6(12.5-19.0)$ & $15.9 \pm 1.5(13.0-19.0)$ & $16(14-19)$ \\
\hline Metacorpus valve width & $12.9 \pm 1.0(11.5-15.0)$ & $12.7 \pm 1.7(11.0-17.0)$ & $12(10-14)$ \\
\hline Vulva slit length & $41.5 \pm 6.2(30.0-51.0)$ & $36.5 \pm 6.0(25.0-52.0)$ & $\ldots$ \\
\hline Vulva-anus distance & $26.6 \pm 4.1(17.0-33.0)$ & $24.4 \pm 3.2(18.0-30.0)$ & $\ldots$ \\
\hline Interphasmidial distance & $25.5 \pm 4.2(19.0-34.0)$ & $22.0 \pm 4.7(15.0-30.0)$ & $\ldots$ \\
\hline \multicolumn{4}{|l|}{ Ratios } \\
\hline $\mathrm{a}=\mathrm{L} / \mathrm{W}$ & $2.0 \pm 0.3(1.6-2.9)$ & $2.0 \pm 0.2(1.7-2.4)$ & $1.45 \pm 0.22(1.11-1.75)$ \\
\hline Stylet knob width/height & $1.7 \pm 0.2(1.5-2.0)$ & $1.8 \pm 0.2(1.5-2.0)$ & $\ldots$ \\
\hline Metacorpus valve L/W & $1.2 \pm 0.1(1.1-1.4)$ & $1.3 \pm 0.2(0.8-1.5)$ & $\ldots$ \\
\hline
\end{tabular}


Biochemical characterization. Young egg-laying females (one, two, and five per tube) of M. megadora were handpicked from infected coffee and bean roots and transferred to microhematocrit tubes with $5 \mu$ l of extraction buffer $(20 \%$ [wt/vol] sucrose and $1 \%$ [vol/vol] Triton X-100) (Esbenshade and Triantaphyllou 1985; Pais et al. 1986). The specimens were macerated with a pestle and stored at $-20^{\circ} \mathrm{C}$. Electrophoresis was performed according to Pais et al. (1986) in vertical gels in a Mini-PROTEAN System (Bio-Rad Laboratories). The gels were stained for esterase and malate dehydrogenase activity with the substrate $\alpha$-naphthyl acetate and malic acid, respectively. Protein extracts of $M$. javanica young egg-laying females were included in each gel as a reference. Phenotypes were designated with a letter or letters suggesting the nematode species, followed by a number indicating the number of bands (Esbenshade and Triantaphyllou 1985). Biochemical procedures were repeated every time that the isolates were used in molecular studies.

Molecular characterization. RAPD. Genomic DNA was extracted from a pellet of RKN J2. Freshly hatched J2 of each isolate (Table 1), obtained from egg masses, were concentrated by centrifugation, frozen in liquid nitrogen, and stored at $-80^{\circ} \mathrm{C}$. Packed juveniles $(50 \mu \mathrm{l})$ were mechanically squashed in a mortar and pestle with $50 \mu l$ of extraction buffer $(0.1 \mathrm{M}$ Tris- $\mathrm{HCl}, \mathrm{pH} 7.5 ; 10 \mathrm{mM}$ EDTA; $0.35 \mathrm{M} \mathrm{NaCl} ; 2 \%$ sodium dodecyl sulfate; and $7 \mathrm{M}$ urea) during $5 \mathrm{~min}$. Then, $50 \mu \mathrm{l}$ of DNA extraction buffer was added and the juveniles were occasionally homogenized during another $15 \mathrm{~min}$. The homogenate was recovered to a sterilized Eppendorf tube with $200 \mu \mathrm{l}$ of extraction buffer. DNA was purified with equal volume of phenol/ chloroform/isoamyl alcohol (24:1:1) for $1 \mathrm{~min}$, mixed by gentle inversion of the Eppendorf tube, and centrifuged at 15,000 rpm for
1 min at $20^{\circ} \mathrm{C}$. The supernatant was transferred to a new Eppendorf tube, 2.5 volumes of absolute ethanol were added to precipitate the DNA, and the mixture was centrifuged at $15,000 \mathrm{rpm}$ for $20 \mathrm{~min}$ at $20^{\circ} \mathrm{C}$. The precipitate was washed with $200 \mu \mathrm{l}$ of ice-cold $70 \%$ ethanol, and dried. The DNA was resuspended in $50 \mu \mathrm{l}$ of sterilized distilled water and the concentration was determined and adjusted to a final concentration of $2 \mathrm{ng} / \mu \mathrm{l}$.

Six random 6-mer primers, four of the Kit G (Operon) and two (SC 10-30 e SC 10-87) providing by R. Waugh (Scottish Crop Research Institute), were tested (Table 2). PCR was performed according to Blok et al. (1997) in a $50 \mu \mathrm{l}$ volume containing $10 \mathrm{ng}$ of nematode DNA, $50 \mathrm{ng}$ of each primer, $1 \times$ buffer, $1.5 \mathrm{mM} \mathrm{MgCl}_{2}, 200 \mu \mathrm{M}$ $\mathrm{dNTP}$, and $1 \mathrm{U}$ of Taq DNA polymerase (Sphaero Q). Mineral oil $(50 \mu \mathrm{l})$ was added on top of each tube with the PCR mixture. The amplifications were carried out in a Cetus Thermal Cycler (PerkinElmer Corporation) using the following conditions: an initial denaturation at $94^{\circ} \mathrm{C}$ for $4 \mathrm{~min}$; followed by 45 cycles of denaturation at $94^{\circ} \mathrm{C}$ for $1 \mathrm{~min}$, annealing at $38^{\circ} \mathrm{C}$ for $2 \mathrm{~min}$, and extension at $72^{\circ} \mathrm{C}$ for $3 \mathrm{~min}$; and a final extension for $10 \mathrm{~min}$ at $72^{\circ} \mathrm{C}$. The PCR reaction $(20 \mu \mathrm{l})$ was analyzed on $1.5 \%$ agarose gel electrophoresis in $1 \times$ Tris-borate-EDTA (TBE) buffer stained with ethidium bromide. The experiment was repeated twice to verify the results.

$r D N A$. M. megadora DNA was extracted from a single female using the DNeasy Blood and Tissue Mini Kit (Qiagen), according to manufacturer's instructions. The ITS rDNA region between $18 \mathrm{~S}$ and $28 \mathrm{~S}$ of rRNA genes was amplified using the primers of Ferris et al. (1993). PCR was performed according to Orui (1996) and amplifications were carried out in a Thermal Cycler (Bio-Rad, Spain) using the following conditions: an initial denaturation at $94^{\circ} \mathrm{C}$ for

Table 4. Morphometric comparison of Meloidogyne megadora Whitehead, 1968 males from coffee and bean ${ }^{\mathrm{a}}$

\begin{tabular}{|c|c|c|c|}
\hline Characteristic & Coffee $(n=20)^{b}$ & Bean $(n=20)^{\text {c }}$ & Coffee $(n=25)^{\mathrm{d}}$ \\
\hline \multicolumn{4}{|l|}{ Linear $(\mu \mathrm{m})$} \\
\hline Body length (L) & $2,280.3 \pm 369.3(1,170.0-2,720.0)$ & $1,863.8 \pm 405.7(1,000.0-2,520.0)$ & $1,906 \pm 330(905-2,277)$ \\
\hline Greatest body width (W) & $47.1 \pm 8.6(33.0-60.5)$ & $46.3 \pm 8.4(28.0-59.5)$ & $\ldots$ \\
\hline Body width at stylet knobs & $21.9 \pm 3.1(18.0-31.0)$ & $19.6 \pm 1.8(16.0-22.0)$ & $\ldots$ \\
\hline Body width at excretory pore & $37.0 \pm 5.4(27.0-46.0)$ & $34.5 \pm 5.0(25.0-44.0)$ & $\ldots$ \\
\hline Lip region height & $3.3 \pm 0.4(2.5-4.0)$ & $2.6 \pm 0.3(2.0-3.0)$ & $5.2 \pm 0.47(4.3-6.1)$ \\
\hline Lip region width & $10.7 \pm 0.9(8.5-12.5)$ & $10.6 \pm 0.9(8.0-12.0)$ & $\ldots$ \\
\hline Lip region to posterior end of metacorpus & $108.1 \pm 17.0(77.0-134.0)$ & $101.4 \pm 12.5(68.0-118.5)$ & $\ldots$ \\
\hline Lip region to metacarpus valve & $93.0 \pm 15.3(65.0-119.0)$ & $87.3 \pm 10.7(59.0-107.0)$ & $\ldots$ \\
\hline Lip region to excretory pore & $158.6 \pm 32.8(89.0-96.0)$ & $149.7 \pm 22.6(82.0-189.0)$ & \\
\hline Stylet length & $21.3 \pm 1.1(18.0-23.0)$ & $20.1 \pm 1.1(18.5-21.5)$ & $20.4 \pm 1.13(18.3-21.9)$ \\
\hline Stylet cone length & $9.9 \pm 0.7(9.0-11.0)$ & $9.0 \pm 0.6(8.0-10.0)$ & $\ldots$ \\
\hline Stylet knob height & $3.7 \pm 0.4(3.0-4.5)$ & $3.3 \pm 0.3(2.5-3.5)$ & $\ldots$ \\
\hline Stylet knob width & $5.7 \pm 0.4(5.0-6.0)$ & $5.1 \pm 0.4(4.5-5.5)$ & $5.1 \pm 0.64(3.6-6.1)$ \\
\hline Dorsal esophageal gland orifice to stylet base & $6.1 \pm 1.2(4.0-8.0)$ & $6.1 \pm 0.5(5.0-7.0)$ & $6.5 \pm 1.18(4.0-8.3)$ \\
\hline Metacorpus width & $11.5 \pm 1.8(7.0-14.0)$ & $12.8 \pm 1.1(10.5-15.0)$ & $\ldots$ \\
\hline Metacorpus valve length & $7.0 \pm 0.8(6.0-8.5)$ & $7.0 \pm 1.1(5.0-8.5)$ & $7.3 \pm 0.98(5.0-8.6)^{\mathrm{e}}$ \\
\hline Metacorpus valve width & $5.2 \pm 0.6(4.0-6.0)$ & $4.8 \pm 0.5(4.0-6.0)$ & $\ldots$ \\
\hline Tail length & $14.4 \pm 2.3(10.0-18.5)$ & $14.8 \pm 3.2(10.0-18.5)$ & $\ldots$ \\
\hline Spicule length & $38.5 \pm 3.3(30.0-43.0)$ & $37.4 \pm 2.3(32.5-43.0)$ & $32.6 \pm 2.96(25.2-36.0)$ \\
\hline Gubernaculum length & $9.9 \pm 0.9(8.0-12.0)$ & $9.0 \pm 0.8(7.5-10.0)$ & $10.6 \pm 0.86(9.4-11.9)^{\mathrm{f}}$ \\
\hline Phasmids to tail tip & $9.6 \pm 1.8(6.0-13.0)$ & $9.2 \pm 1.9(5.0-12.5)$ & $\ldots$ \\
\hline Interphasmidial distance & $25.5 \pm 4.2(19.0-34.0)$ & $22.0 \pm 4.7(15.0-30.0)$ & $\ldots$ \\
\hline \multicolumn{4}{|l|}{ Ratios } \\
\hline $\mathrm{a}=\mathrm{L} / \mathrm{W}$ & $49.3 \pm 9.4(35.5-67.4)$ & $40.1 \pm 3.8(33.2-45.8)$ & $52.8 \pm 7.06(36.9-62.8)$ \\
\hline $\mathrm{c}$ & $161.4 \pm 31.5(97.5-237.0)$ & $126.1 \pm 20.7(93.3-174.2)$ & $137.0 \pm 29.9(98.0-218.0)^{\mathrm{e}}$ \\
\hline Lip region width/height & $3.3 \pm 0.4(2.5-4.2)$ & $4.1 \pm 0.4(3.2-4.8)$ & $\ldots$ \\
\hline Stylet knob width/height & $1.6 \pm 0.2(1.3-2.0)$ & $1.6 \pm 0.1(1.3-1.8)$ & $\ldots$ \\
\hline Metacorpus valve L/W & $4.0 \pm 0.2(1.2-1.8)$ & $1.5 \pm 0.2(1.0-1.9)$ & $\ldots$ \\
\hline \multicolumn{4}{|l|}{ Percentage } \\
\hline Excretory pore & $7.0 \pm 1.0(4.5-8.7)$ & $8.2 \pm 1.1(6.6-10.7)$ & $\ldots$ \\
\hline
\end{tabular}

\footnotetext{
a Values are means \pm standard error (range).

${ }^{\mathrm{b}}$ Field population.

${ }^{c}$ Data from one line culture.

d Original description (Whitehead 1968).

e $n=24$.

${ }^{\mathrm{f}} n=13$.
} 
$4 \mathrm{~min}$; followed by 40 cycles of denaturation at $94^{\circ} \mathrm{C}$ for $1 \mathrm{~min}$, annealing at $45^{\circ} \mathrm{C}$ for $1 \mathrm{~min}$, and extension at $72^{\circ} \mathrm{C}$ for $1.5 \mathrm{~min}$; and a final extension for $10 \mathrm{~min}$ at $72^{\circ} \mathrm{C}$. The PCR products were analyzed on $1 \%$ agarose gel in $1 \times$ TBE buffer stained with GreenSafe (NZYTech).

The amplified products were purified with the QIAquick PCR Purification Kit (Qiagen) and quantified using the NanoDrop 2000C Spectrophotometer (Thermo Scientific), according to the manufacturer's instructions. Amplified DNA was cloned and three selected positive clones were sequenced by standard procedures at Macrogen, Inc. Chromatograms were checked and corrected manually by use of the BioEdit software (Hall 1999). The clones of rDNA M. megadora sequences were deposited in the GenBank as KU559895, KU559896, and KU559897.

Phylogenetic analysis. RAPD. Bands were scored as present or absent directly from the gels and only DNA fragments consistently present or absent between the two repeats were recorded and considered. DNA fingerprints from each isolate were converted to a 0-to-1 matrix, and the phylogenetic analyses was conducted using the program PHYLIP, version 3.5c (Felsenstein 1993; Sneath and Sokal 1973). The distance-based neighbor-joining (NJ) algorithm was used with the unweighted pair-group method with arithmetic means in the Gendist program (Nei 1972). Dendrograms were obtained with the Treeview program, 1,000 bootstrap replicates were performed to test the support of nodes for the most parsimonious tree, and a consensus dendrogram was computed (Nei 1972). Primers OPG-9 and SC 10-87 were not included in the analyses: no reproducible results were obtained and no amplification occurred with these primers, respectively.
rDNA. M. megadora sequences were aligned using Muscle (Edgar 2004) with homologs of Meloidogyne spp. sequences. Alignment was manually adjusted when necessary. The phylogenetic relationship was reconstructed according to Maleita et al. (2012).

\section{Results}

Biometrical characterization. Morphometrics of adult females and males and $\mathrm{J} 2$ of two $M$. megadora isolates maintained in coffee and bean are given in Tables 3 to 5 . Adult females of M. megadora showed an oval or elongated to pear shaped body, large, and asymmetrical; some females had a protuberance and a well-defined tail. Neck was distinct, sometimes quite long, projecting sideward at an angle to the longitudinal body axis (Fig. 1 A and B). Lip region was not set off from the body. Oval prestoma; six inner labial sensilla surround the prestoma; labial disc square, raised above the medial lips, with four bumps; medial lips rectangular, in face view, with two bumps and a pair of cephalic sensilla; large lateral triangular, fused with medial lips; amphidial openings oval (Fig. 1A to C). Conical part of stylet was curved dorsally. Shaft becomes broader posteriorly and knobs are backward sloping, transverse elongate, and distinctly set off from the shaft. They are deeply indented anteriorly, usually with one groove (in one specimen, two grooves) (Fig. 1D and E). Excretory pore was located posterior to stylet base, 19 to 28 annules from head end and 10 to 19 annules from stylet base. Hemizonid posterior five to six annules to excretory pore.

Perineal patterns were variable in shape, although some of the features could be recognized as distinctive (Fig. $1 \mathrm{~F}$ to $\mathrm{H}$ ). Shape of the perineal pattern was rounded, composed of fine, wavy striae, often

Table 5. Morphometric comparison of Meloidogyne megadora Whitehead, 1968 second-stage juveniles from coffee and bean ${ }^{\mathrm{a}}$

\begin{tabular}{|c|c|c|c|}
\hline Characteristic & Coffee $(n=20)^{b}$ & $\operatorname{Bean}(n=20)^{\mathrm{c}}$ & Coffee $(n=25)^{\mathrm{d}}$ \\
\hline \multicolumn{4}{|l|}{ Linear $(\mu \mathrm{m})$} \\
\hline Body length (L) & $434.5 \pm 27.6(370.0-485.0)$ & $470.8 \pm 25.1(410.0-510.0)$ & $451.0 \pm 27.0(413-548)$ \\
\hline Greatest body width (W) & $16.1 \pm 0.9(15.0-18.0)$ & $16.3 \pm 1.1(15.0-18.5)$ & $\ldots$ \\
\hline Body width at stylet knobs & $11.1 \pm 0.7(10.0-12.0)$ & $10.8 \mathrm{v} 1.0(9.3-13.0)$ & $\ldots$ \\
\hline Body width at excretory pore & $15.0 \pm 0.7(13.5-16.5)$ & $15.0 \pm 0.8(13.8-17.0)$ & $\ldots$ \\
\hline Body width at anus & $11.2 \pm 1.0(10.0-13.0)$ & $11.0 \pm 0.7(10.0-12.5)$ & $\ldots$ \\
\hline Lip region height & $2.1 \pm 0.2(1.8-2.5)$ & $1.9 \pm 0.2(1.5-2.0)$ & $\ldots$ \\
\hline Lip region width & $5.7 \pm 0.4(5.0-6.5)$ & $5.5 \pm 0.4(5.0-6.0)$ & $\ldots$ \\
\hline Lip region to posterior end of metacorpus & $60.4 \pm 4.1(51.0-67.5)$ & $63.4 \pm 2.7(58.0-70.0)$ & $\ldots$ \\
\hline Lip region to metacarpus valve & $52.3 \pm 4.0(44.0-60.0)$ & $55.0 \pm 2.8(51.0-62.0)^{\mathrm{e}}$ & $\ldots$ \\
\hline Lip region to excretory pore & $80.3 \pm 9.5(65.0-108.0)$ & $83.9 \pm 5.0(73.0-91.0)$ & $\ldots$ \\
\hline Lip region to stylet base & $15.6 \pm 0.6(14.0-17.0)$ & $15.7 \pm 0.6(14.3-17.0)$ & $\ldots$ \\
\hline Stylet length & $12.5 \pm 1.0(11.0-15.0)$ & $11.5 \pm 0.7(10.3-13.0)$ & $12 \pm 0.61(10.7-13.2)^{\mathrm{f}}$ \\
\hline Stylet knob height & $1.7 \pm 0.2(1.2-2.0)$ & $1.4 \pm 0.2(1.0-1.5)$ & $\ldots$ \\
\hline Stylet knob width & $2.3 \pm 0.2(2.0-2.5)$ & $2.0 \pm 0.2(1.5-2.5)$ & $\ldots$ \\
\hline Dorsal esophageal gland orifice to stylet base & $4.1 \pm 0.5(3.5-5.0)$ & $3.6 \pm 0.4(3.0-5.0)$ & $3.9 \pm 1.14(2.3-4.8)^{\mathrm{g}}$ \\
\hline Metacorpus valve length & $4.1 \pm 0.2(3.5-4.5)$ & $3.8 \pm 0.5(3.0-5.5)$ & $4.6 \pm 0.63(3.2-6.5)$ \\
\hline Metacorpus valve width & $3.7 \pm 0.3(3.0-4.4)$ & $3.4 \pm 0.3(3.0-4.0)$ & $\ldots$ \\
\hline Tail length & $58.0 \pm 5.3(48.5-76.0)$ & $57.9 \pm 4.6(51.0-70.0)$ & $53.0 \pm 3.0(47.0-58.0)$ \\
\hline Hyaline tail terminus length & $16.7 \pm 3.1(10.6-23.5)$ & $16.4 \pm 3.8(8.0-23.0)$ & $\ldots$ \\
\hline Hyaline tail terminus width & $4.5 \pm 0.8(3.0-6.0)$ & $4.4 \pm 0.7(3.0-6.0)$ & $\ldots$ \\
\hline \multicolumn{4}{|l|}{ Ratios } \\
\hline $\mathrm{a}=\mathrm{L} / \mathrm{W}$ & $27.1 \pm 2.2(23.3-32.3)$ & $29.0 \pm 2.9(22.8-33.0)$ & $27.8 \pm 2.31(23.1-32.9)$ \\
\hline $\mathrm{c}$ & $7.5 \pm 0.8(5.8-9.5)$ & $8.2 \pm 0.9(6.5-9.6)$ & $8.4 \pm 0.6(7.6-11.0)$ \\
\hline Lip region width/height & $2.8 \pm 0.2(2.4-3.3)$ & $3.0 \pm 0.3(2.5-3.7)$ & $\ldots$ \\
\hline Stylet knob width/height & $1.4 \pm 0.2(1.0-2.1)$ & $1.5 \pm 0.2(1.2-2.0)$ & $\ldots$ \\
\hline Body length/lip region to metacorpus valve & $8.3 \pm 0.6(7.6-9.5)$ & $8.1 \pm 0.3(7.6-8.8)^{\mathrm{f}}$ & $\cdots$ \\
\hline Metacorpus valve $\mathrm{L} / \mathrm{W}$ & $1.1 \pm 0.1(1.0-1.4)$ & $1.1 \pm 0.1(0.9-1.6)$ & $\ldots$ \\
\hline Tail length/hyaline tail terminus length & $3.6 \pm 0.7(2.4-5.6)$ & $3.8 \pm 1.3(2.4-7.5)$ & $\ldots$ \\
\hline \multicolumn{4}{|l|}{ Percentage } \\
\hline Excretory pore & $18.5 \pm 2.1(15.1-24.7)$ & $17.8 \pm 1.0(15.5-19.5)$ & $\ldots$ \\
\hline
\end{tabular}

a Values are means \pm standard error (range).

${ }^{b}$ Field population.

${ }^{c}$ Data from one line culture.

d Original description (Whitehead 1968).

e $n=10$.

${ }^{\mathrm{f}} n=25$.

$\mathrm{g}_{n}=4$. 
broken. Dorsal arch was low and rounded. Cuticle often folded in dorsal region of pattern. Anal fold present. Phasmids were fairly close to tail terminus. Vulva was wider than interphasmidial distance. Some horizontal, fine, broken striations between vulva and anus. $\mathrm{Ru}-$ dimentary lateral field was marked by breaks in the striae and minute disordered striae within the field. Sometimes, concentric circles of striae formed a distinct raised tail pattern; some of the striae were directed toward angles of vulva.
Adult male lengths ranged from 1,170 to 2,720 and 1,000 to $2,520 \mu \mathrm{m}$ for coffee and bean, respectively, with the anterior end slightly tapered, tail conoid, bluntly rounded, and terminus not striated (Table 4; Fig. 1I to M). Head cap was low, truncate, narrower than the head region; head region not set off, without annulations or with a few (one to four) irregular, incomplete lines. Labial disc was round, elevated, fused with medial lips; lateral lips absent. Stoma was slit-like, located in ovoid prestomatal cavity surrounded
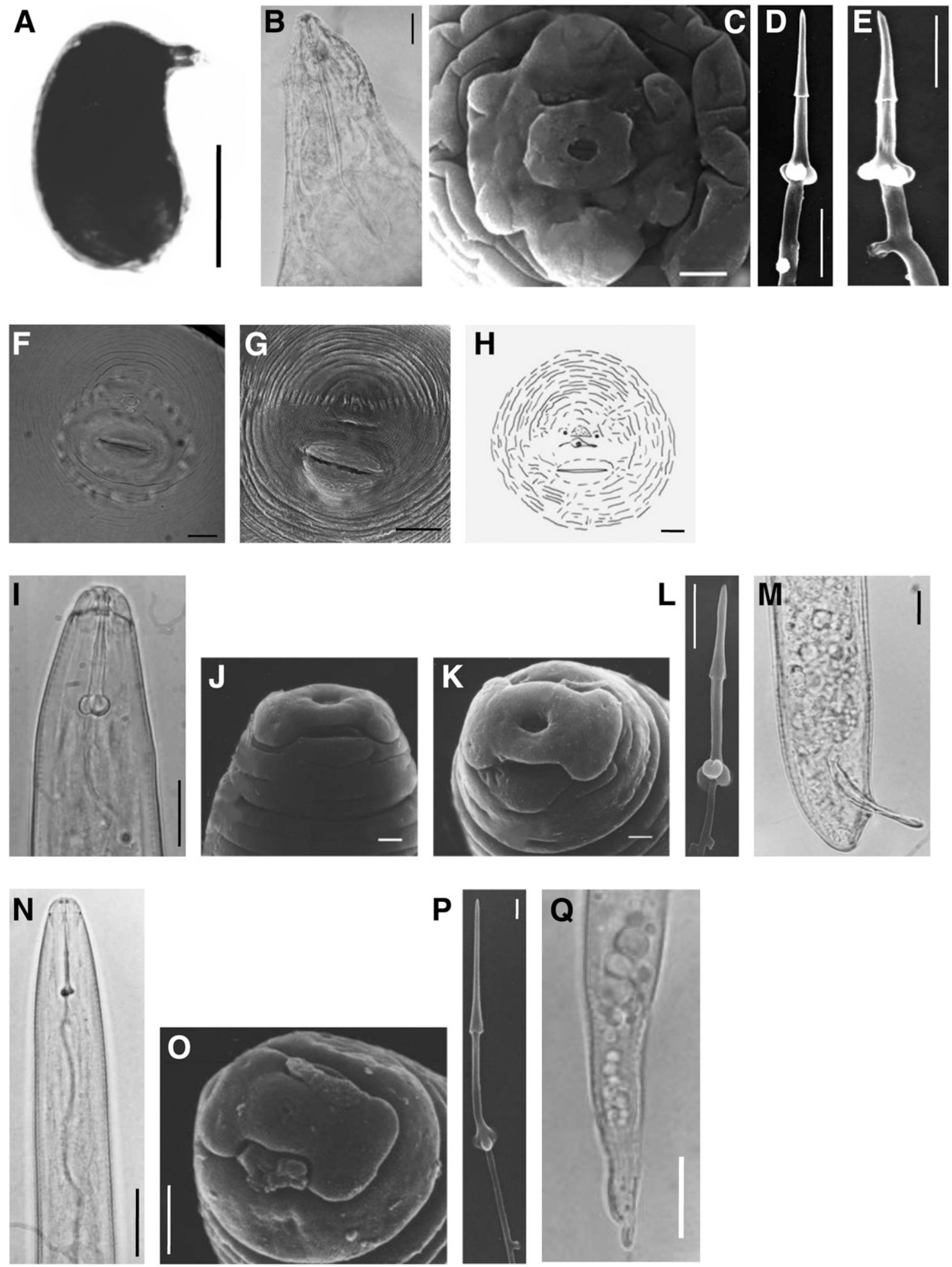

Fig. 1. A, B, F, I, M, N, and Q, light microscope photographs; C, D, E, G, J, K, L, O, and P, scanning electron microscope photographs; and H, schematic representation of perineal pattern of Meloidogyne megadora Whitehead, 1968. Females: A, whole specimen; $\mathbf{B}$ and $\mathbf{C}$, anterior end and esophageal region; $\mathbf{D}$ and $\mathbf{E}$, excised stylets; and $\mathbf{F}$ to $\mathbf{H}$, perineal patterns. Males: I and J, anterior region in lateral view; $\mathbf{K}$, lip region showing inner labial sensilla; $\mathbf{L}$, excised stylet; and $\mathbf{M}$, posterior region in lateral view. Second-stage juveniles: $\mathbf{N}$, anterior region; O, lip region; P, excised stylet; and Q, tail region. Scale bars: $500 \mu \mathrm{m}(\mathrm{A}), 20 \mu \mathrm{m}(\mathrm{G}), 10 \mu \mathrm{m}(\mathrm{E}, \mathrm{F}, \mathrm{H}, \mathrm{L}, \mathrm{M}$, and P), $5 \mu \mathrm{m}(\mathrm{C})$, and $1 \mu \mathrm{m}$ (C, D, I, J, K, N, and O). 

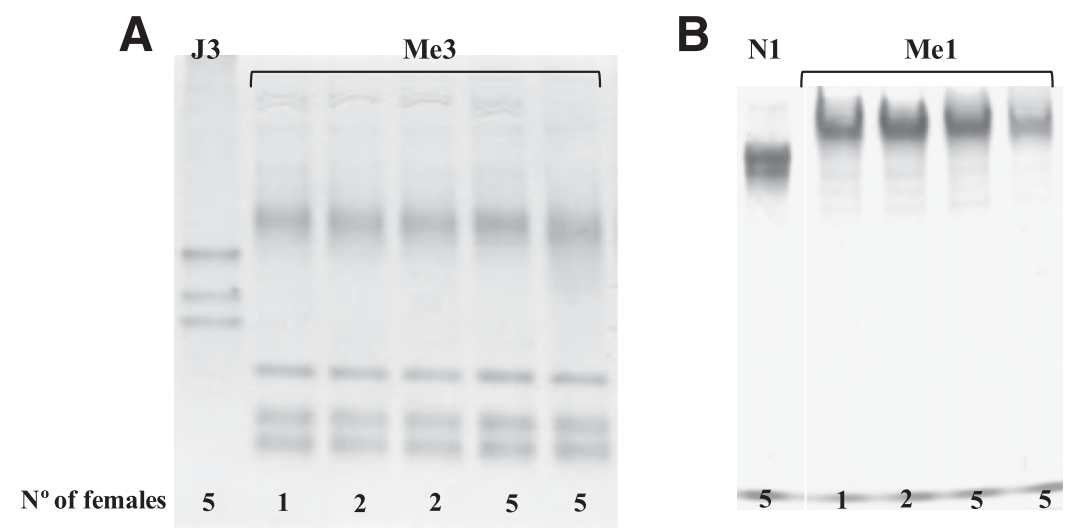

Fig. 2. A, Esterase and B, malate dehydrogenase phenotypes of protein homogenates from one, two, and five egg-laying females of Meloidogyne megadora Whitehead, 1968. Me3 and Me1 = M. megadora and J3 and N1 = M. javanica (Treub, 1885) Chitwood, 1949 (reference isolate).

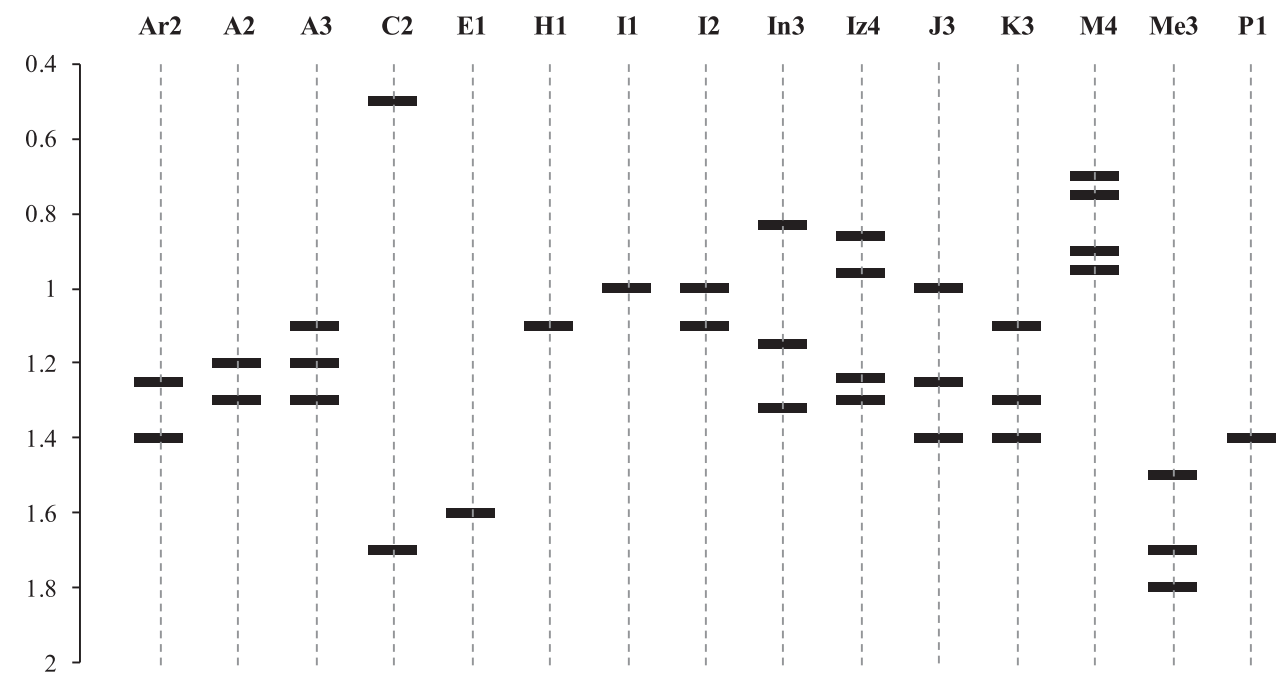

Fig. 3. Comparative diagram of esterase phenotypes of 13 of 17 Meloidogyne spp. found associated with coffee. Ar2 = Meloidogyne arabicida López and Salazar, 1989; A2 and A3 = M. arenaria (Neal, 1889) Chitwood, 1949; C2 = M. coffeicola Lordello and Zamith, 1960; E1 = M. exigua Göldi, 1887; H1 = M. hapla Chitwood, 1949; I1 and I2 = M. incognita (Kofoid and White, 1919) Chitwood, 1949; In3 = M. inornata Lordello, 1956; Iz4 = M. izalcoensis Carneiro, Almeida, Gomes and Hernández, 2005; J3 = M. javanica (Treub, 1885) Chitwood, 1949; K3 = M. konaensis Eisenback, Bernard and Schmitt, 1995; M4 = M. enterolobii Yang and Eisenback, 1983 (= M. mayaguensis Rammah and Hirschmann, 1988); Me3 = M. megadora Whitehead, 1968; and P1 = M. paranaensis Carneiro, Carneiro, Abrantes, Santos and Almeida, 1996.

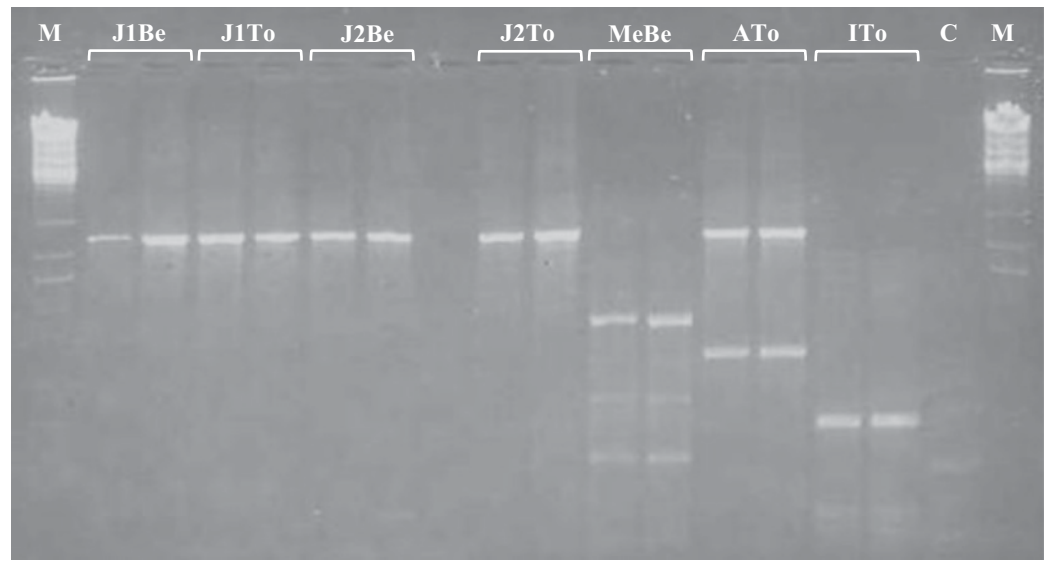

Fig. 4. Random amplified polymorphic DNA patterns from second-stage juveniles of Meloidogyne megadora Whitehead, 1968 (Me), M. javanica (Treub, 1885 ) Chitwood, 1949 (J), M. arenaria (Neal, 1889) Chitwood, 1949 (A), and M. incognita (Kofoid and White, 1919) Chitwood, 1949 (I) obtained with primer OPG-4. DNA was extracted and purified from isolates maintained on tomato (To) and bean (Be). $\mathrm{C}=$ negative control and $\mathrm{M}=\mathrm{DNA}$ marker (Phage Lambda DNA digested by EcoRI and HindllI). 
by pore-like openings of six inner labial sensilla; four cephalic sensilla marked by cuticular depressions on medial lips; amphid apertures elongate slits. Cephalic framework was moderately developed. Vestibule and extension distinct. In most males, stylet was robust, opening about $3.0 \mu \mathrm{m}$ from stylet tip; cone bluntly pointed at tip, widening in diameter posteriorly; in dwarf males (body length $<1,200 \mu \mathrm{m}$ ), approximately $8 \%$ of the 75 observed, stylet was thinner than in normal ones. Procorpus and metacorpus distinct, metacorpus elongate. Hemizonid distinct, about $3.0 \mu \mathrm{m}$ long, variable in position: in front of, or anterior to (one annule), or posterior to (two annules) the excretory pore. Lateral field usually with four incisures; in some areas, one more incisure was present; two outer bands were not completely aerolated. Testes predominantly one, two occasionally (4\%), several with reflexed germinal zone. Spicules long, the distal half nearly straight; gubernaculum weakly curved in lateral view. Phasmids posterior to cloacal level.

Body length of $\mathrm{J} 2$ varied from 370 to 485 and 410 to $510 \mu \mathrm{m}$ for coffee and bean, respectively (Table 5). Lip region was offset with one to three irregular, incomplete annulations. Labial disc was slightly raised above the rounded-off medial lips; lateral lips elongate, in same contour with the lip region; labial disc and medial lips dumbbell-shaped in face view. Prestoma opening was ovoid, surrounded by small, pore-like openings of six inner labial sensilla. Cephalic sensilla was expressed externally as small, round, cuticular depressions (Fig. 1N and O). Cephalic framework weak. Stylet moderately long. Stylet cone gradually increases in width posteriorly; shaft cylindrical, slightly wider near the middle knobs elongate and gradually merge with the shaft (Fig. 1P). Lateral field was marked by four incisures, weakly areolated. Excretory pore distinct. Hemizonid, two to three annules long, at the level of the excretory pore, in two specimens appears anterior, adjacent to the nerve ring. Tail long (mean length of $58.0 \mu \mathrm{m}$ ), with constrictions along the length and near the terminal part, which ends in a narrow, rounded tip; hyaline terminus long (mean length $16.0 \mu \mathrm{m}$ ) (Table 5; Fig. 1Q). Tail shape was variable, even in a cohort of one female.

Differential host test. Results showed that all North Carolina differential hosts were nonhosts of M. megadora (gall/egg masses $=0$ ).

Biochemical characterization. Native polyacrylamide gel electrophoresis gave reproducible esterase and malate dehydrogenase banding profiles and the enzymatic activity was detected from homogenates prepared with 1,2 , or 5 females. A characteristic phenotype was shown to $M$. megadora with three electrophoretic bands (Relative mobility $[\mathrm{Rm}]=0.68,0.77$, and 0.82 ) for the nonspecific esterases or one $(\mathrm{Rm}=0.17)$ for malate dehydrogenases $($ Fig. 2$)$. The $M$. javanica isolate included in each gel as reference showed three bands of esterase activity $(\mathrm{Rm}=0.45,0.54$, and 0.59$)$ and one of malate dehydrogenase activity $(\mathrm{Rm}=0.22)($ Fig. 2$)$.

The esterase phenotype of M. megadora was compared with the available phenotypes for the Meloidogyne spp. identified associated with coffee (Fig. 3). All of them contained distinct and speciesspecific phenotypes. The esterase phenotype of M. megadora was clearly distinct from the other Meloidogyne spp. (Fig. 3).

Table 6. Genetic distance between Meloidogyne megadora Whitehead, 1968 (MeBe); M. arenaria (Neal, 1889) Chitwood, 1949 (ATo); M. incognita (Kofoid and White, 1919) Chitwood, 1949 (ITo); and M. javanica (Treub, 1885) Chitwood, 1949 (race 1: J1To and J1Be; race 2: J2To and J2Be) according to Nei index (Nei 1972)

\begin{tabular}{lccccccc}
\hline Isolate code $^{\mathbf{a}}$ & MeBe & ATo & ITo & J1Be & J1To & J2Be & J2To \\
\hline MeBe & 0.000 & $\ldots$ & $\ldots$ & $\ldots$ & $\ldots$ & $\ldots$ & $\ldots$ \\
ATo & 1.398 & 0.000 & $\ldots$ & $\ldots$ & $\ldots$ & $\ldots$ & $\ldots$ \\
ITo & 1.216 & 0.587 & 0.000 & $\ldots$ & $\ldots$ & $\ldots$ & $\ldots$ \\
J1Be & 1.216 & 0.050 & 0.544 & 0.000 & $\ldots$ & $\ldots$ & $\ldots$ \\
J1To & 1.216 & 0.050 & 0.544 & 0.000 & 0.000 & $\ldots$ & $\ldots$ \\
J2Be & 1.216 & 0.050 & 0.544 & 0.000 & 0.000 & 0.000 & $\ldots$ \\
J2To & 1.216 & 0.050 & 0.544 & 0.000 & 0.000 & 0.000 & 0.000 \\
\hline
\end{tabular}

${ }^{\mathrm{a}}$ Codes ending in To and Be indicate isolates maintained on tomato (Solanum lycopersicum L.) and bean (Phaseolus vulgaris L.), respectively.
Molecular characterization. In order to evaluate the genetic variation between Meloidogyne spp., comparative analyses were performed by RAPD-PCR. No amplification occurred with the primer SC 10-87 and no reproducible results were obtained with primer OPG-9. With the remaining five primers, RAPD-PCR analyses resulted in a reproducible banding pattern. Primer SC 10-30 produced specific bands to $M$. incognita and $M$. megadora and primers OPG-4, OPG-5, and OPG-6 to all species studied (Fig. 4, data for primer OPG-4).

The ITS region, partial sequence of $18 \mathrm{~S}$ rRNA gene, complete sequences of ITS 1 (5.8S) and 2, and partial sequence of 28S rRNA gene were selected to carry out the molecular characterization of $M$. megadora isolate. This region, amplified with the primers pair of Ferris et al. (1993) from purified DNA extracted from a single female, yielded a single fragment of approximately $700 \mathrm{bp}$ (data not shown).

The PCR products were first directly sequenced and multiple peaks in the sequencing chromatogram were observed, suggesting the presence of more than one sequence. Then, these PCR products were cloned and three clones were analyzed. Sequences of $641 \mathrm{bp}$ were obtained, with three nucleotide changes at positions 67, 252, and 386 (data not shown).

Phylogenetic analysis. RAPD. M. megadora displayed genetic distances ranging from 1.216 ( $M$. incognita and $M$. javanica) to 1.398 (M. arenaria) (Table 6). The two M. javanica isolates, with different geographical origins and obtained from different hosts (bean and tomato), formed a well-supported clade and was a sister taxon to $M$. arenaria. $M$. incognita is the species closest of $M$. megadora, which was the most divergent species (Fig. 5).

rDNA. Dendrograms obtained from both $\mathrm{NJ}$ and maximumlikelihood (ML) analyses of ITS rRNA sequences of several Meloidogyne spp. available in GenBank were similar, except that the ML tree M. panyuensis Liao, Yang, Feng and Karssen, 2005 clustered with M. mali Itoh, Ohshima and Ichinohe, 1969 with low bootstrap support (34\%), and the clade formed by M. baetica Castillo, Vovlas, Subbotin and Troccoli, 2003 and M. artiellia Franklin, 1961 was a sister taxa of the clade which included the most common RKN species. However, only the NJ tree is exhibited with bootstrap values (Fig. 6). The dendrogram obtained from NJ analysis showed that Meloidogyne spp. formed one clade with high bootstrap support (98\%), with the exclusion of M. megadora, M. panyuensis, M. mali, M. baetica, and

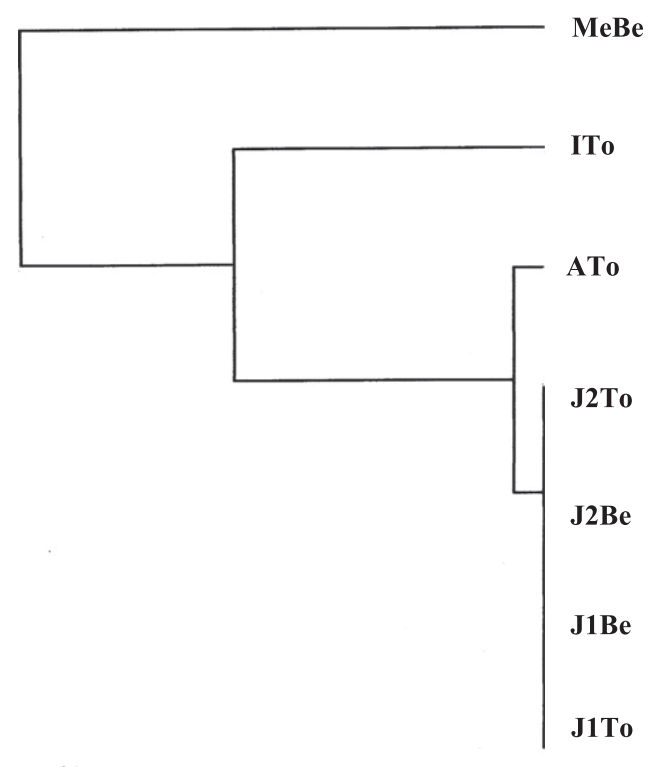

Fig. 5. Dendrogram of similarity of Meloidogyne megadora Whitehead, $1968(\mathrm{Me})$, M. arenaria (Neal, 1889) Chitwood, 1949 (A), M. incognita (Kofoid and White, 1919) Chitwood, 1949 (I), and M. javanica (Treub, 1885) Chitwood, 1949 race 1 (J1) and race $2(\mathrm{~J} 2)$ isolates obtained from genetic distances between species based on unweighted pair-group method with arithmetic means. Isolates were maintained on tomato (To) and/or bean (Be). 
M. artiellia. First, M. arenaria, M. incognita, and M. javanica were clustered together with high bootstrap support (99\%) and as a sister taxa to M. enterolobii and M. hispanica Hirschmann, 1986. Second, M. naasi Franklin, 1965; M. trifoliophila Bernard and Eisenback,
1997; M. minor Karssen, Bolk, van Aelst, van den Beld, Kox, Korthals, Molendijk, Zijlstra, van Hoof and Cook, 2004; M. chitwoodi Golden, O'Bannon, Santo and Finley, 1980; and M. fallax Karssen, 1996 formed a clade (60\%) with M. hapla. M. marylandi Jepson and

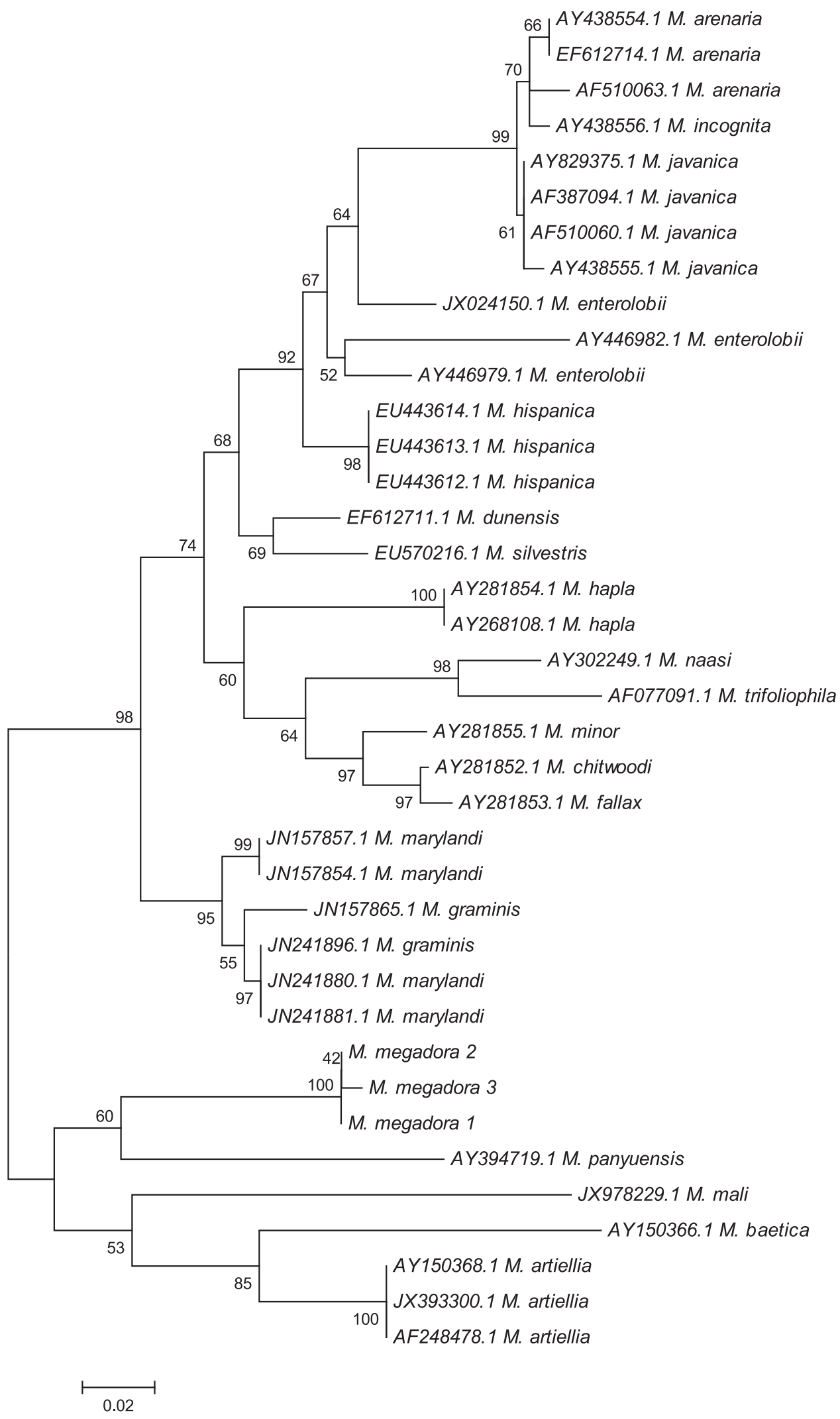

Fig. 6. Neighbor-joining tree based on analysis of alignment and adjusting the length of sequences of internal transcribed spacer ribosomal DNA (rDNA) region between $18 \mathrm{~S}$ and $28 \mathrm{~S}$ of rRNA genes of tree Meloidogyne megadora Whitehead, 1968 clones with available sequences of other Meloidogyne spp. Evolutionary distances were computed using the maximum composite likelihood method. All positions containing gaps and missing data were eliminated. 
Golden in Jepson, 1987 and M. graminis (Sledge and Golden, 1964) Whitehead, 1968 clustered together with $95 \%$ bootstrap support. All M. megadora clones clustered together with high bootstrap (100\%) and as a sister taxon to $M$. panyuensis $(60 \%)$. M. artiellia isolates clustered together and as a sister taxon to M. baetica (85\%) (Fig. 6).

\section{Discussion}

M. megadora, which parasitizes economically important crops such as coffee and can be regularly confused with other RKN species, is one of the most unknown Meloidogyne spp. The potential impact of this species on coffee areas reinforces the need for an accurate and rapid identification based on morphological, biological, biochemical, and molecular characteristics.

Diagnosis based on morphology is not always easy even for qualified taxonomists due to the great inter- and intramorphological and physiological variability and to the frequent occurrence of more than one species in the same sample (Eisenback 1985).

Range values of the morphometric characteristics for adult females and males and $\mathrm{J} 2$ of the two M. megadora isolates (coffee and bean) overlapped or were within the expected range according to the original description (Whitehead 1968). Morphology of the M. megadora isolates developmental stages was similar to the original description (Whitehead 1968) and distinct from other Meloidogyne spp. found associated with coffee (Carneiro and Cofcewicz 2008).

Body length of $M$. megadora females, perineal pattern morphology, and number of incisures in lateral field of males are useful characteristics to use to differentiate this species (4 incisures) from $M$. decalineata (10 incisures), with which it was erroneously associated in the past (Lordello and Fazuoli 1980; Santos et al. 1992). Male cone length was less than half of stylet length. According to Jepson (1987), $M$. megadora was included in one of the two groups defined on the basis of that relationship, together with M. africana.

$M$. megadora failed to be infectious in all differential host plants. The four most common Meloidogyne spp. which were also found associated with coffee can reproduce on most differential host plant cultivars (egg mass index $>2$ ): $M$. arenaria (all hosts except 'Deltapine' cotton and 'Florunner' peanut), M. hapla (all hosts except cotton and 'Charleston Gray' watermelon), M. incognita (all hosts except cotton, peanut, and tobacco 'NC95'), and M. javanica (all hosts except cotton, 'California Wonder' pepper, and peanut). Relative to the other RKN species that parasitize coffee, the reaction of differential host plant cultivars was only reported for $M$. paranaensis that reproduces in watermelon, tobacco, and tomato and does not reproduce in cotton, peanut, and pepper (Carneiro et al. 1996b). This test is currently out of a diagnostic tool of RKN species due to the variation among the species, the substantial number of new species described, and the presence of more than one species in the same field (Moens et al. 2009).

Currently, biochemical electrophoretic analysis of nonspecific esterases remains the most common, rapid, and efficient method for RKN species identification when females are available, being very useful in the detection of populations with more than one species (Abrantes et al. 2008; Brito et al. 2008; Carneiro et al. 1996a, 2000; Castro et al. 2003; Cofcewicz et al. 2004). The esterase phenotype of M. megadora (Me3), three bands with high mobility, is unique, clearly distinct from the other Meloidogyne spp. and, consequently, very useful to differentiate this species from other RKN species found associated with coffee. However, the observation of intraspecific variability and similarity between species and the discovery of new esterase patterns make necessary the use of additional information to confirm the identification (Blok and Powers 2009).

Genetic variation was detected by RAPD-PCR between $M$. megadora and Meloidogyne spp. included in this study. Visual analysis indicated that all Meloidogyne spp. and isolates studied were different and could be discriminated. However, to unambiguously discriminate these species and validate the results, a larger number of isolates from different hosts and geographical origins should be included in further studies. Previous studies have showed a similarity of $>40 \%$ in some $M$. javanica populations collected from Brazil (Carneiro et al. 1998). Nevertheless, intraspecific genetic variability of $M$. arenaria
(40 to $67 \%$ ), M. incognita (45 to $56 \%$ ), and $M$. javanica (41 to $73 \%$ ) was found (Devran et al. 2008). Amplification with primer OPG-4 resulted in distinct fragments for $M$. megadora, $M$. javanica, $M$. incognita, and $M$. arenaria. Distinct fragments could be excised from the gel, cloned, sequenced, and converted into an RKN species-specific primer, in particular to M. megadora, to be applied when only $\mathrm{J} 2$ are available. Amplification with primers OPE- 07 and K7 resulted in a fragment of 350 and $520 \mathrm{bp}$ specific to M. ethiopica Whitehead, 1968 and M. enterolobii, respectively. These fragments were converted into sequence-characterized amplified region markers, which are applied in routine diagnostic procedures (Correa et al. 2013; Tigano et al. 2010).

The relationships between isolates of $M$. arenaria, M. hapla, M. incognita, $M$. javanica, and $M$. enterolobii were studied by RAPD using most of the primers used herein and it was found that $M$. javanica isolates form a single group closest to $M$. arenaria (Blok et al. 1997). Our results are in agreement with Blok et al. (1997): M. javanica isolates clustered together closer to M. arenaria, and M. megadora was the most distinct species.

The ITS rDNA region has been used for molecular characterization at the species level and construction of phylogenies of RKN (Castillo et al. 2003; Landa et al. 2008; Palomares Rius et al. 2007; Tigano et al. 2005). The most common RKN species (M. arenaria, $M$. incognita, and $M$. javanica) formed a well-supported clade and as a sister taxa to $M$. enterolobii and $M$. hispanica. This group includes the obligate mitotic parthenogenetic RKN. M. hapla (reproduction by facultative meiotic or mitotic parthenogenesis) grouped (60\% of bootstrap support) with $M$. naasi, M. trifoliophila, M. minor, M. chitwoodi, and M. fallax (meiotic parthenogenetic pathogens).

Multiple peaks were observed in ITS rDNA sequencing chromatograms, suggesting the presence of more than one ribosomal sequence for $M$. megadora. Sequence analyses of the three $M$. megadora clones for ITS rDNA region revealed intraindividual molecular diversity, which should be taken into account when this region is used as molecular marker for $M$. megadora identification and characterization. This result is in accordance with that described by Hugall et al. (1999) for the four most common RKN species.

All M. megadora clones (reproduction by mitotic parthenogenesis, unpublished results) clustered together and grouped with M. panyuensis, M. mali, M. baetica, and M. artiellia, for which the mode of reproduction has not yet been studied. Considering the main clades, our results also agree with those obtained by Castillo et al. (2003), Tigano et al. (2005), Palomares Rius et al. (2007), and Landa et al. (2008). Phylogenetic analysis showed that ITS rDNA sequences present enough divergence to differentiate $M$. megadora from other RKN species such as $M$. arenaria, $M$. hapla, $M$. incognita, $M$. javanica, and M. enterolobii found associated with coffee; however, only one isolate was included in this study. Thus, if possible, a broad range of M. megadora isolates from different hosts and geographical origins should be obtained and more than one molecular characteristic examined.

M. megadora clearly differs from other RKN infecting coffee in the shape of the perineal pattern, number of incisures in lateral field of males, esterase phenotype (Me3), and molecular characterization of the ITS rDNA region between $18 \mathrm{~S}$ and $28 \mathrm{~S}$ of rRNA genes. In routine diagnostic procedures, isozyme analysis remains an effective methodology to unambiguously identify and differentiate $M$. megadora when females are available in field root samples.

\section{Acknowledgments}

We thank M. S. N. de Almeida Santos, from the University of Coimbra, Portugal, for fruitful discussions, suggestions, and comments. This research was financed by FCT/MEC through national funds, with co-funding by the FEDER, within the PT2020 Partnership Agreement and COMPETE 2020, within the project UID/BIA/04004/2013, and by Instituto do Ambiente, Tecnologia e Vida C. Maleita (SFRH/BPD/85736/2012) was financed by MEC National funding and The European Social Fund through Programa Operacional Capital Humano.

\section{Literature Cited}

Abrantes, I. M. de O., Arias, M., Bello, A. Espírito Santo, S. N. do, Lamberti, F., Reis, L. G., Rodrigues, C. J., Jr., Santos, M. S. N. de A., and Vovlas, N. 1995a. Nemátodes do cafeeiro na República de São Tomé e Príncipe e selecção de cultivares resistentes. Comun. Ser. Cienc. Agrar. 19:131-141. 
Abrantes, I. M. de O., and Santos, M. S. N. de A. 1989. A technique for preparing perineal patterns of root-knot nematodes for scanning electron microscopy. J. Nematol. 21:138-139.

Abrantes, I. M. de O., and Santos, M. S. N. de A. 1991. Meloidogyne lusitanica n. sp. (Nematoda: Meloidogynidae), a root-knot nematode parasitizing olive tree (Olea europaea L.). J. Nematol. 23:210-224.

Abrantes, I. M. de O., Santos, M. S. N. de A., and Vovlas, N. 1995b. Studies on Meloidogyne megadora found in coffee plantations in Républica de S. Tomé e Príncipe. Nematologica 41:278.

Abrantes, I. M. de O., Vieira dos Santos, M. C., da Conceição, I. L. P. M., Santos, M. S. N. de A., and Vovlas, N. 2008. Root-knot and other plant-parasitic nematodes associated with fig trees in Portugal. Nematol. Mediterr. 36:131136.

Almeida, A. M. S. F. de, and Santos, M. S. N. de A. 2002. Resistance and hostresponse of selected plants to Meloidogyne megadora. J. Nematol. 34:140-142.

Almeida, A. M. S. F. de, Santos, M. S. N. de A., and Ryan, M. F. 1997. Host status of selected plant species for Meloidogyne megadora. Nematropica 27:1-6.

Blok, V. C., Phillips, M. S., McNicol, J. W., and Fargette, M. 1997. Genetic variation in tropical Meloidogyne spp. as show by RAPDs. Fundam. Appl. Nematol. 20:127-133.

Blok, V. C., and Powers, T. O. 2009. Biochemical and molecular identification. Pages 98-118 in: Root-Knot Nematodes. R. N. Perry, M. Moens, and J. L. Starr, eds. CABI Publishing, Wallingford, UK.

Brito, J. A., Kaur, R., Cetintas, R., Stanley, J. D., Mendes, M. L., McAvoy, E. J., Powers, T. O., and Dickson, D. W. 2008. Identification and isozyme characterisation of Meloidogyne spp. infecting horticultural and agronomic crops, and weed plants in Florida. Nematology 10:757-766.

Campos, V. P., Sivapalan, P., and Gnanapragasam, N. C. 1990. Nematode parasites of coffee, cocoa and tea. Pages 387-430 in: Plant Parasitic Nematodes in Subtropical and Tropical Agriculture. M. Luc, R. A. Sikora, and J. Bridge, eds. CAB International, Wallingford, UK.

Carneiro, R. M. D. G., Almeida, M. R. A., and Carneiro, R. G. 1996a. Enzyme phenotypes of Brazilian populations of Meloidogyne spp. Fundam. Appl. Nematol. 19:555-560.

Carneiro, R. M. D. G., Almeida, M. R. A., and Quénéhervé, P. 2000. Enzyme phenotypes of Meloidogyne spp. populations. Nematology 2:645-654.

Carneiro, R. M. D. G., Carneiro, R. G., Abrantes, I. M. de O., Santos, M. S. N. A., and Almeida, M. R. A. 1996b. Meloidogyne paranaensis n. sp. (Nematoda: Meloidogynidae), a root knot nematode parasitizing coffee in Brazil. J. Nematol. 28:177-189.

Carneiro, R. M. D. G., Castagnone-Sereno, P., and Dickson, D. W. 1998. Variability among four populations of Meloidogyne javanica from Brazil. Fundam. Appl. Nematol. 21:319-326.

Carneiro, R. M. D. G., and Cofcewicz, E. T. 2008. Taxonomy of coffee-parasitic root-knot nematodes, Meloidogyne spp. Pages 87-122 in: Plant-Parasitic Nematodes of Coffee. R. M. Souza, ed. Springer Science+Business Media B.V. Campos dos Goytacazes (RJ), Brazil.

Castillo, P., Vovlas, N., Subbotin, S., and Troccoli, A. 2003. A new root knot nematode, Meloidogyne baetica $\mathrm{n}$. sp. (Nematoda: Heteroderidae), parasitizing wild olive in southern Spain. Phytopathology 93:1093-1102.

Castro, J. M. da C. E., Lima, R. D. de, and Carneiro, R. M. D. G. 2003. Isoenzymatic variability in Brazilian populations of Meloidogyne spp. from soybean. Nematol. Bras. 27:1-12.

Cofcewicz, E. T., Carneiro, R. M. D. G., Castagnone-Sereno, P., and Quénéhervé, P. 2004. Enzyme phenotypes and genetic diversity of root-knot nematodes parasitising Musa in Brazil. Nematology 6:85-95.

Correa, V. R., Mattos, V. S., Almeida, M. R. A., Santos, M. F. A., Tigano, M. S., Castagnone-Sereno, P., and Carneiro, R. M. D. G. 2013. Genetic diversity of the root-knot nematode Meloidogyne ethiopica and development of a speciesspecific SCAR marker for its diagnosis. Plant Pathol. 63:476-483.

Decker, H., Yassin, A. M., and El-Amin, E. T. M. 1980. Plant nematology in the Sudan, a review article. Z. Angew. Zool. 67:1-20.

Devran, Z., Sögüt, M. A., Gözel, U., Tör, M., and Elekcioglu, I. H. 2008. Analysis of genetic variation between populations of Meloidogyne spp. from Turkey. Russ. J. Nematol. 16:143-149.

Edgar, R. C. 2004. MUSCLE: Multiple sequence alignment with high accuracy and high throughput. Nucleic Acids Res. 32:1792-1797.

Eisenback, J. D. 1985. Techniques for preparing nematodes for scanning electron microscopy. Pages 79-105 in: An Advanced Treatise on Meloidogyne, Vol. II. Methodology. K. R. Barker, C. C. Carter, and J. N. Sasser, eds. Department of Plant Pathology and the United States Agency for International Development, North Carolina State University Graphics, Raleigh.

Esbenshade, P. R., and Triantaphyllou, A. C. 1985. Use of enzyme phenotypes for identification of Meloidogyne species. J. Nematol. 17:6-20.

Felsenstein, J. 1993. Phylogenie Inference Package. Version 3.5c. Department of Genetics, University of Washington, Seattle.
Ferris, V. R., Ferris, J. M., and Faghihi, J. 1993. Variation in spacer ribosoma DNA in some cyst-forming species of plant parasitic nematodes. Fundam. Appl. Nematol. 16:177-184.

FAO. 2012. Production/crops processed-Coffee, green. Online publication. Food and Agriculture Organization of the United Nations, Statistics Division. http:// faostat3.fao.org/faostat-gateway/go/to/browse/Q/QC/E

Hall, T. A. 1999. BioEdit: a user friendly biological sequence alignment editor and analyses program for windows 95/98/NT. Nucleic Acids Symp. Ser. 41:95-98.

Hartman, K. M. 1982. Enhancement technique for egg masses of the root-knot nematode with Phloxine B. Page 130 in: Proc. Third Res. Plan. Conf. RootKnot Nematodes, Meloidogyne spp. Region II. Lima, Peru. North Carolina State University Graphics, Raleigh.

Hartman, K. M., and Sasser, J. N. 1985. Identification of Meloidogyne species on the basis of differential host test and perineal-pattern morphology. Pages 69-77 in: An Advanced Treatise on Meloidogyne, Vol. II. Methodology. K. R. Barker, C. C. Carter, and J. N. Sasser, eds. North Carolina State University Graphics, Raleigh.

Hugall, A., Stanton, J., and Moritz, C. 1999. Reticulate evolution and the origins of ribosomal internal transcribed spacer diversity in apomictic Meloidogyne. Mol. Biol. Evol. 16:157-164.

Hussey, R. S., and Barker, K. R. 1973. A comparison of methods of collecting inocula of Meloidogyne spp., including a new technique. Plant Dis. Rep. 57: 1025-1028

Jepson, S. B. 1987. Identification of Root Knot Nematodes (Meloidogyne Species) Commonwealth Agricultural Bureaux International, Wallingford, Oxon, UK.

Landa, B. B., Palomares Rius, J. E., Vovlas, N., Carneiro, R. M. D. G., Maleita, C. M. N., Abrantes, I. M. de O., and Castillo, P. 2008. Molecular characterization of Meloidogyne hispanica (Nematoda, Meloidogynidae) by phylogenetic analysis of genes within the rDNA in Meloidogyne spp. Plant Dis. 92:1104-1110.

Lordello, R. R. A., and Fazuoli, L. C. 1980. Meloidogyne decalineata parasita cafeeiros na ilha de São Tomé. Rev. Agric. Piracicaba 55:238.

Maleita, C. M., Simões, M. J., Egas, C., Curtis, R. H. C., and Abrantes, I. M. de O. 2012. Biometrical, biochemical, and molecular diagnosis of Portuguese Meloidogyne hispanica isolates. Plant Dis. 96:865-874

Moens, M., Perry, R. N., and Starr, J. L. 2009. Meloidogyne species-A diverse group of novel and important plant parasites. Pages 1-17 in: Root Knot Nematodes. R. N. Perry, M. Moens, and J. L. Starr, eds. CABI Publishing, Wallingford, UK

Nei, M. 1972. Genetic distance between populations. Am. Nat. 106:283-292.

Orui, Y. 1996. Discrimination of the main Pratylenchus species (Nematoda: Pratylenchidae) in Japan by PCR-RFLP analysis. Appl. Entomol. Zool. (Jpn.) 31:505-514.

Pais, C. S., Abrantes, I. M. de O., Fernandes, M. F. M., and Santos, M. S. N. de A 1986. Técnica de electroforese aplicada ao estudo das enzimas dos nemátodesdas-galhas-radiculares, Meloidogyne spp. Ciênc. Biol. Ecol. Syst. Portugal 6:19-34

Palomares Rius, J. E., Vovlas, N., Troccoli, A., Liébanas, G., Landa, B. B., and Castillo, P. 2007. A new root-knot nematode parasitizing sea rocket from Spanish Mediterranean coastal dunes: Meloidogyne dunensis n. sp. (Nematoda: Meloidogynidae). J. Nematol. 39:190-202.

Santos, M. S. N. de A., Abrantes, I. M. de O., Rodrigues, A. C. F. de O., Espirito Santo, S. N., and Joaquim, P. 1992. Root-knot nematodes in coffee in the Democratic Republic of São Tomé e Príncipe. Nematologica 38:434.

Sneath, P. H., and Sokal, R. R. 1973. Numerical Taxonomy: The Principles and Practice of Numerical Classification. W.H. Freeman and Co., San Francisco.

Taylor, A. L., and Sasser, J. N. 1978. Biology, identification and control of rootknot nematodes (Meloidogyne spp.). Department of Plant Pathology, North Carolina State University and the United States Agency for International Development, North Carolina State University Graphics, Raleigh.

Tigano, M., Siqueira, K., Castagnone-Sereno, P., Mulet, K., Queiroz, P., dos Santos, M., Teixeira, C., Almeida, M., Silva, J., and Carneiro, R. 2010 Genetic diversity of the root-knot nematode Meloidogyne enterolobii and development of a SCAR marker for this guava-damaging species. Plant Pathol. 59:1054-1061.

Tigano, M. S., Carneiro, R. M. D. G., Jeyaprakash, A., Dickson, D. W., and Adams, B. J. 2005. Phylogeny of Meloidogyne spp. based on 18S rDNA and the intergenic region of mitochondrial DNA sequences. Nematology 7 : 851-862.

Whitehead, A. G. 1968. Taxonomy of Meloidogyne (Nematoda: Heteroderidae) with descriptions of four new species. Trans. Zool. Soc. Lond. 31:263-401.

Whitehead, A. G. 1969. The distribution of root-knot nematodes Meloidogyne spp. in tropical Africa. Nematologica 15:315-333.

Yassin, A. M., and Zeidan, A. B. 1982. Root-knot nematodes in the Sudan, 1982 round-off report. Pages 131-135 in: Proc. Third Res. Plan. Conf. Root-Knot Nematodes, Meloidogyne spp., Region VII, Coimbra, Portugal. North Carolina State University Graphics, Raleigh.

Zhang, S., and Weng, Z. 1991. Identification of root-knot nematode species in Fujian. J. Fujian Agric. Coll. 20:158-164. 